UNITED STATES DEPARTMENT OF THE INTERIOR

GEOLOGICAL SURVEY

\title{
Geochemical Survey of the Unaka Mountain Roadless Area,
}

Unicoi County, Tennessee

By

K. A. Duttweiler, W. R. Griffitts, J. W. Whitlow, and E. F. Cooley

Open-File Report $84-268$

This report is prel iminary and has not been reviewed for conformity with U.S. Geological Survey editorial standards. Any use of trade names is for descriptive purposes only and does not imply endorsement by the U.S. Geological Survey. 


\section{CONTENTS}

Page

Studies related to wilderness..................................

Summary................................................

Introduction. .........................................

Geology.................................................

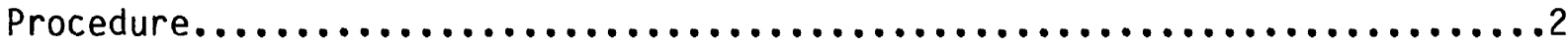

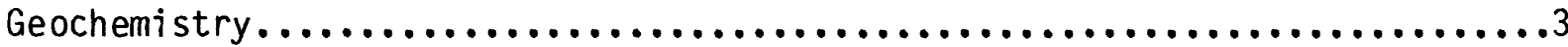

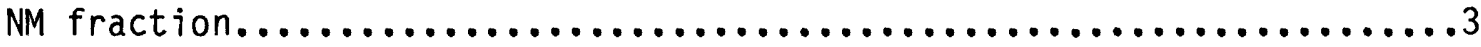

M1 fraction.....................................

M.5 fraction.....................................

References cited........................................

\section{TABLES}

Table 1.--Limits of determination for the spectrographic analysis of rocks and stream sediments based on a 10 -mg sample........6

Table 2.--Analytical data for heavy-mineral concentrates from the Unaka Mountain Roadless Area, Tennessee................7

\section{ILLUSTRATIONS}

Plate 1. Geochemical survey of the Unaka Mountains Roadless Area, Unicoi County, Tennessee..................... In pocket

Figure A. Location of the Unaka Mountain Roadless Area

B. Geologic map and sample sites of the Unaka Mountain Roadless Area

C. Tin, copper, and barium contents of nonmagnetic heavy-mineral concentrates

D. Lead and thorium contents of magnetic (M1) fraction of heavy-mineral concentrates

E. Copper, lead, and zinc contents of magnetic (M.5) fraction of heavy-mineral concentrates 


\section{Studies Related to Wilderness}

The Wilderness Act (Public Law 88-577, September 3, 1964) and related acts require the U.S. Geological Survey and the U.S. Bureau of Mines to survey certain areas on Federal Lands to determine their mineral resource potential. Results must be made available to the public and be submitted to the President and the Congress. This report presents the results of a geochemical survey of the Unaka Mountain Roadless Area, Forest Service number 08275, in the Cherokee National Forest, Unicoi County, Tennessee. The Unaka Mountain Roadless Area was classified as a non-wilderness area during the Second Roadless Area Review and Evaluation (RARE II) by the U.S. Forest Service, January 1979.

\section{SUMMARY}

Unaka Mountain Roadless Area comprises 4,700 acres in the Cherokee National Forest, Unicoi County, Tennessee. The area is underlain by a Precambrian-to-Cambrian sequence of gneiss and granite, sandstone, quartzite, and shale. Iron and manganese prospects and mines are scattered throughout a dolomite unit just outside of the Roadless Area. Panned concentrates from major drainages within and just outside of the Roadless Area contained significant values of lead, thorium, copper, tin, zinc, and barium. Concentrations of these elements were plotted showing their distributions. Lead and thorium are ubiquitous and are likely contained in monazite that is reworked from the Precambrian basement rocks. Copper and zinc may be contained in iron oxides after magnetite. Barium and tin-rich concentrates are derived from streams draining clastic rocks and Precambrian granites and gneiss in the northern and northeastern parts of the area.

\section{INTRODUCTION}

The Unaka Mountain Roadless Area is in the Cherokee National Forest in the Blue Ridge physiographic province. The area lies entirely in Unicoi County, about $21 / 2 \mathrm{mi}$ south of Stone Mountain. The North Carolina-Tennessee state boundary nearly parallels the southern border of the Roadless Area (plate 1; figure A). Access to the area is primarily by dirt roads and trails. Limestone Cove and Davis Springs al ong State Route 107 are the nearest towns, about $2 \mathrm{mi}$ north of the area. The town of Erwin, Tennessee, is within $3 \mathrm{mi}$ of the Roadless Area. Rock Creek, Dick Creek, and several other tributaries of North Indian Creek comprise the drainages. Relief is moderate to steep; and vegetation is thick in most places.

In the spring of $1980, K$. A. Duttweiler, J.W. Whitlow, and W. R. Griffitts of the U.S. Geological Survey conducted a reconnaissance geochemical survey of the Unaka Mountain Roadless Area. The purpose of this report is to provide a brief summary of the geology and assess the geochemical nature of the area.

\section{GEOLOGY}

The general geology of the Roadless Area and adjacent areas is shown in Plate 1 (figure B). The geology was mapped by King and others (1944) and was used in this report to aid in the interpretation of the geochemical data. There was no additional mapping conducted by the authors. A brief description 
of rock units is provided here. For any additional details on geology or structure, refer to King and others (1944), King and Ferguson (1960), or Rodgers (1952).

The Unaka Mountain Roadless Area lies in the Limestone Cove window bounded by the Limestone Cove and Unaka Mountain thrust faults (King and Ferguson, 1960). Strata strike northeast and dip northwest.

Nearly 98 percent of the study area is underlain by the basal clastic rocks of Lower Cambrian series called the Chilhowee Group. Underlying Precambrian rocks comprise the remaining 2 percent. The Shady Dolomite overlies the Chilhowee Group and occurs only outside of the study area.

The Precambrian rocks that crop out in the far southeast corner of the study area consist of medium-grained granites and fine-grained Cranberry gneiss. The Chilhowee Group includes the Unicoi, Hampton, and Erwin Formations, which for simplicity, were combined as the Chilhowee Group in Plate 1 (figure B). However, descriptions of each of the three formations are included.

The oldest and lowermost formation in the Chilhowee Group is the Unicoi Formation, which is exposed in over 90 percent of the area. The formation consists of thick-bedded quartzite, in part arkosic and conglomeratic, that is interbedded with thin-bedded arkose.

The Hampton Formation, which overlies the Unicoi Formation, is generally thought of as a shaly interval between the more sandy or quartzitic Unicoi and Erwin Formations. The Hampton Formation is composed mainly of dark gray to greenish gray clay shale with interbedded layers of siltstone and arkosic sandstone in the lower part of the formation and vitreous quartzite in the upper part. The Hampton is not exposed in the Unaka Mountain Roadless Area, but the slope break which parallels the northern boundary represents the Unicoi-Hampton contact.

The Erwin Formation is the uppermost unit of the Chilhowee Group and consists of white vitreous quartzite, dark ferruginous quartzite, siltstone, and shale. The white quartzite beds constitute a relatively small part of the formation, but serve to distinguish the Erwin Formation from the otherwise similar Hampton Formation. Based on mapping by Rodgers (1952), small portions of the area are underlain by the Erwin Formation.

The Shady Dolomite, which is also of Cambrian age, crops out 2 to $3 \mathrm{mi}$ west and north of the study area. Numerous iron and manganese prospects and mines are scattered throughout the dolomite. The occurrence of iron and manganese oxides in the Shady Dolomite is common in many parts of northeastern Tennessee (King and others, 1944).

\section{PROCEDURE}

Samples were collected from 34 drainages, each drainage representing a 1to 1.5-sq mi area. Some samples were collected from drainages just outside of the Unaka Mountain Roadless Area boundary. Nevertheless, the samples are important in evaluating the geochemical nature of the area. Sample locations are listed by field number (table 2) and are shown in Plate 1 (figure B). At 
each sample site, a stream-sediment sample was collected and heavy-mineral-concentrate samples were panned from the same active alluvium as the stream-sediment samples. The heavy-mineral concentrates were used in evaluating the Unaka Mountain area, because the common rock-forming minerals (quartz and feldspar) which tend to dilute the stream-sediment sample are removed, leaving the heavier ore-forming minerals.

Each concentrate was sieved through a 20-mesh screen to remove the coarse material. The light minerals (quartz and feldspar) still remaining after panning were removed by bromoform separation. Magnetite was removed with a hand magnet. Using a Frantz Isodynamic magnetic separator with a $15^{\circ}$ side slope and $25^{\circ}$ forward slope setting, three fractions were obtained: the magnetic at 0.5 ampere (M.5), the magnetic at 1 ampere (M1), and the nonmagnetic at 1 ampere (NM). The NM fraction generally contains the most common ore-forming sulfide and oxide minerals as well as other nonmagnetic minerals such as zircon, rutile, fluorite, and topaz.

Mineral proportions of each fraction were estimated with a binocular microscope. Many samples contained contaminants such as copper wire or lead shot, which were removed at this stage. Each fraction was subsequently analyzed semiquantitatively by $E$. F. Cooley for 31 elements using a six-step d.c. arc, optical-emission spectrographic method (Grimes and Marranzino, 1968). The values are reported as one of six steps per order of magnitude: $1,0.7,0.5,0.3,0.2,0.15$, and multiples of these numbers. These values are the approximate midpoints of the concentration ranges.

\section{GEOCHEMISTRY}

Of the 31 elements analyzed, concentrations of lead, thorium, copper, zinc, tin, and barium were significant and their distributions are shown in Plate 1 (figures $C-E$ ). The semiquantitative analysis of the samples are listed in the Table 2 .

\section{NM fraction}

The highest values of tin and copper were found in the NM fraction along with enriched barium values. The three elements were plotted together in Plate 1 (figure $C$ ).

The limit of detection for barium by spectrographic analysis is $50 \mathrm{ppm}$. All of the values in the NM fraction are at or greater than this amount. Barium values ranged from 50 to $3000 \mathrm{ppm}$. The highest values of 700 to 3000 were found in concentrates obtained from streams draining the northeast section of the Unaka Mountain Roadless Area, an area containing clastic rocks of the Chilhowee Group.

Copper values ranged from 20 to $300 \mathrm{ppm}--\mathrm{a} 1 \mathrm{l}$ above the lower limit of detection of $10 \mathrm{ppm}$ for copper. Sample $80 \mathrm{Uk} 33$ was taken from a stream draining the Chilhowee Group near the Limestone Cove overthrust and contained 300 ppm copper. Samples $80 U K 32$ and 80 UK9 were taken from near the thrust contact in the same drainage basin as 80UK33, and had values of only $50 \mathrm{ppm}$. Sample 80UK34, also taken from this drainage basin, had $30 \mathrm{ppm}$. 
Tin is detectable down to $20 \mathrm{ppm}$. Most samples did not contain enough tin to be detectable; the values obtained ranged from 20 to $500 \mathrm{ppm}$. The highest values occur in the east and northeastern parts of the area. Sample $80 U K 40$ was obtained from a stream outside of the Unaka Mountain Roadless Area boundary, and contained $500 \mathrm{ppm}$ tin. Sample $80 U K 47$ was obtained close to the Unaka Mountain thrust contact between Precambrian rocks and the clastic rocks of the Chilhowee Group just east of the area and contained $300 \mathrm{ppm}$ tin. Furthur downstream in this drainage basin containing 80UK47, however, tin is not present in great enough quantity to be detected. Samples 80UK7 and 80UK8 contained insufficient NM fraction after heavy-liquid separation and magnetic separation for semiquantitative spectrographic analysis.

It was not possible to establish the host minerals for tin, copper, or barium. During examination of the NM fraction with a binocular microscope, no cassiterite nor any recognizable copper or barium minerals were observed.

\section{M1 Fraction}

Lead and thorium were ubiquitous in the M1 fraction. The distributions of both elements are shown in Plate 1 (figure D).

Lead is detectable by spectrographic analysis to $20 \mathrm{ppm}$. All values of lead in the Ml fraction were above this limit and ranged from 50 to 1000 ppm. Generally, the highest values were obtained from concentrates of streams just northeast of the area. Sample $800 k 7$ is from a stream that drains the Precambrian rocks and contained the highest value of $1000 \mathrm{ppm}$. Sample 80 UK 8 contained insufficient sample for analysis. There are six samples which were obtained from drainage basins entirely within the rocks of the Chilhowee Group. The values for these six samples were between 100 and $500 \mathrm{ppm}$ lead. Sample $800 k 22$ yielded a value of $500 \mathrm{ppm}$ and was from a stream draining Precambrian rocks just north of the area and north of the thrust. The southern and southeastern areas yielded values of 50 to $200 \mathrm{ppm}$.

Thorium occurred in nearly all M1 samples. By spectrographic analysis, thorium is not detectable below $200 \mathrm{ppm}$. Values for thorium range from 200 $\mathrm{ppm}$ to greater than $2000 \mathrm{ppm}$. Samples obtained from drainages in both Chilhowee Group rocks in the northern part of the area and Precambrian rocks southeast of the area yielded high values.

Lead and thorium occur together in nearly every sample. Monazite was observed in most M1 samples. Some M1 samples contained 50 to 80 percent monazite, which is the probable source of the lead and thorium. Inasmuch as the monazite is widespread, particularly in the northern and northeastern areas, it is probably reworked from the older Precambrian rocks.

\section{M.5 Fraction}

Highest values of zinc occur in the M.5 fraction. Copper and lead are enriched in the M.5 fraction and have a wide range of values. The distributions of the three elements are plotted together in Plate 1 (figure $E$ ).

Whenever zinc is detected, it is considered significant because of the very high detection limit of $500 \mathrm{ppm}$. Ten samples contained $500 \mathrm{ppm}$ zinc. 
Samples $80 U K 46$ and $80 U K 7$ were obtained from streams draining both Precambrian gneissic rocks and clastic rocks east of the area. Both samples were close to the Unaka Mountain thrust contact. Other samples containing $500 \mathrm{ppm}$ zinc were obtained from streams in the northern portion of the area, an area underlain by the Chilhowee Group rocks.

Samples $80 \mathrm{UK} 35$ and $80 \mathrm{UK} 36$ contained 1000 and $500 \mathrm{ppm}$ zinc, respectively. Both were taken from drainages outside of the Unaka Mountain Roadless Area boundary and at the Limestone Cove thrust contact.

Copper and lead are enriched in many samples. Copper values of 10 to 150 ppm are widespread. There are several enriched values near the Limestone Cove thrust southwest of the area. Lead values range from 20 to $100 \mathrm{ppm}$ with the highest values in the northern part.

It is difficult to determine the host minerals for the zinc or copper as no minerals containing them were recognized with a binocular microscope. Because the zinc and copper are enriched in the M.5 fraction, they are most likely contained in iron oxides after magnetite. Monazite was present in small amounts in the M.5 fraction and is the likely source of the lead.

\section{REFERENCES CITED}

Grimes, D. J., and Marranzino, A. P., 1968, Direct-current arc and alternating-current spark emission spectrographic field methods for the semiquantitative analysis of geologic materials: U.S. Geological Survey Circular 591, 6 p.

King, P. B., and Ferguson, H. W., 1960, Geology of northeasternmost Tennessee: U.S. Geological Survey Professional Paper 311, 136 p.

King, P. B., Ferguson, H. W., Craig, L. C., and Rodgers, John, 1944, Geology and Manganese Deposits of Northeastern Tennessee: Tennessee Division of Geology Bulletin 52, $275 \mathrm{p}$.

Rodgers, John, 1952, Geologic map of east Tennessee: Tennessee Division of Geology Bullet in 58, part II, 1:125,000 scale maps, 15 plates. 
Table 1.--Limits of determination for the spectrographic analysis of rocks and stream sediments, based on a $10-\mathrm{mg}$ sample

[The spectrographic limits of determination for heavy-mineral-concentrate samples are two reporting units higher than the limits given for rocks and stream sediments.]

Elements

Lower determination limit

Upper determination limit

\section{Percent}

Parts per million

$\begin{array}{lcr}\text { Iron (Fe) } & 0.05 & 20 \\ \text { Magnesium (Mg) } & .02 & 10 \\ \text { Calcium ( Ca) } & .05 & 20 \\ \text { Titanium ( Ti) } & .002 & 1\end{array}$

(1)

\begin{tabular}{|c|c|c|}
\hline \multicolumn{3}{|c|}{ Parts per million } \\
\hline Manganese (Mn) & 10 & 5,000 \\
\hline Silver $(\mathrm{Ag})$ & 0.5 & 5,000 \\
\hline Arsenic (As) & 200 & 10,000 \\
\hline Gold $(A u)$ & 10 & 500 \\
\hline Boron (B) & 10 & 2,000 \\
\hline Barium (Ba) & 20 & 5,000 \\
\hline Beryllium (Be) & 1 & 1,000 \\
\hline Bi smuth $(B i)$ & 10 & 1,000 \\
\hline Cadmium (Cd) & 20 & 500 \\
\hline Cobalt (Co) & 5 & 2,000 \\
\hline Chromium (Cr) & 10 & 5,000 \\
\hline Copper (Cu) & 5 & 20,000 \\
\hline Lanthanum (La) & 20 & 1,000 \\
\hline Molybdenum (Mo) & 5 & 2,000 \\
\hline Niobium (Nb) & 20 & 2,000 \\
\hline Nickel (Ni) & 5 & 5,000 \\
\hline Lead $(P b)$ & 10 & 20,000 \\
\hline Antimony (Sb) & 100 & 10,000 \\
\hline Sc andium (Sc) & 5 & 100 \\
\hline $\operatorname{Tin}(S n)$ & 10 & 1,000 \\
\hline Strontium (Sr) & 100 & 5,000 \\
\hline Vanadium (V) & 10 & 10,000 \\
\hline Tungsten (W) & 50 & 10,000 \\
\hline Yttrium $(Y)$ & 10 & 2,000 \\
\hline $\operatorname{Zinc}(\mathrm{Zn})$ & 200 & 10,000 \\
\hline Zirconium ( $\mathrm{Zr}$ ) & 10 & 1,000 \\
\hline Thorium (Th) & 100 & 2,000 \\
\hline
\end{tabular}




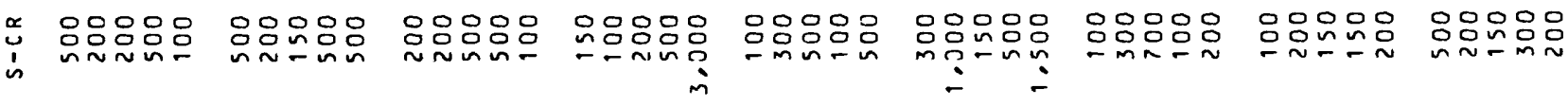

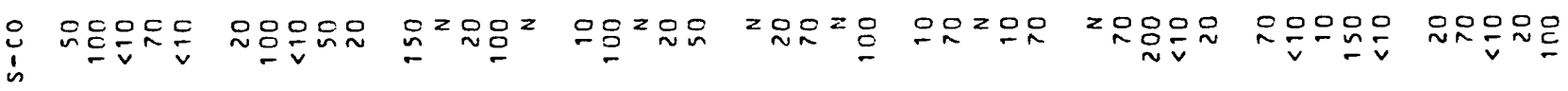

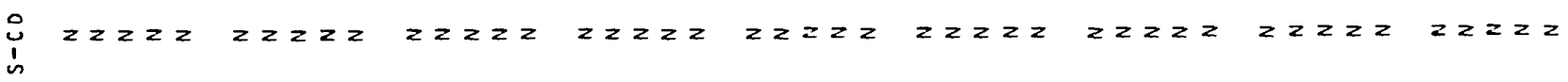

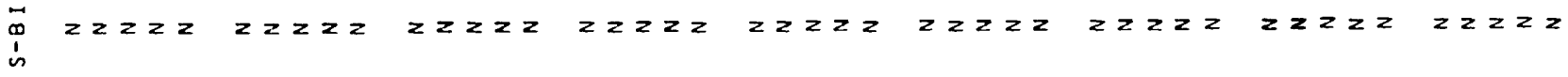

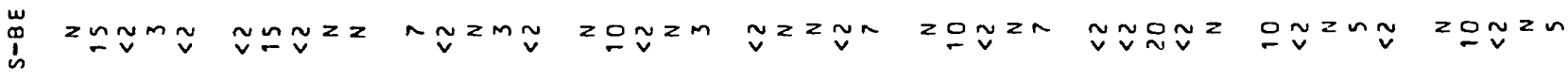

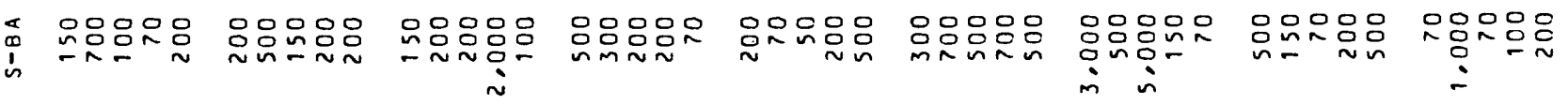

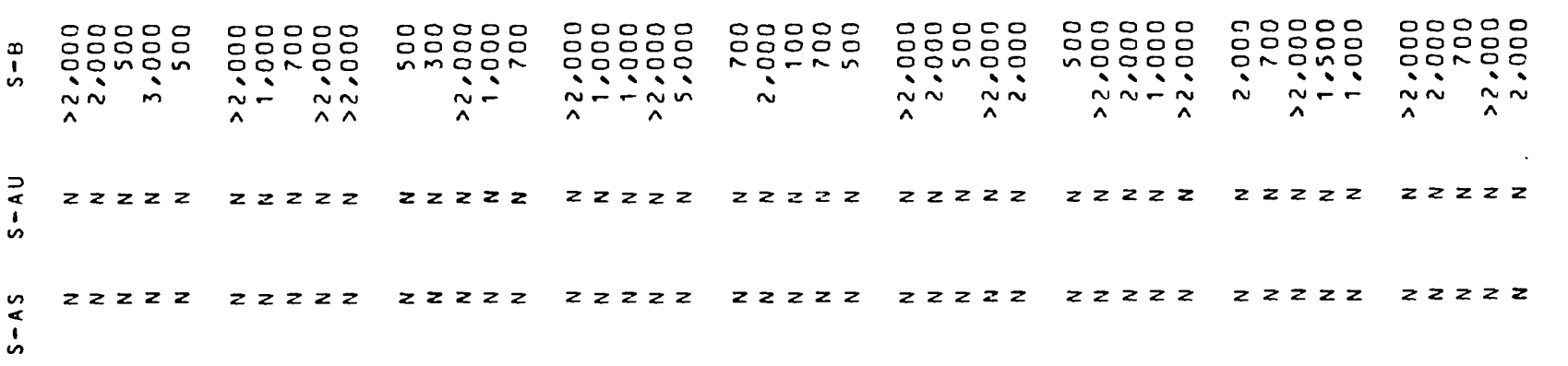

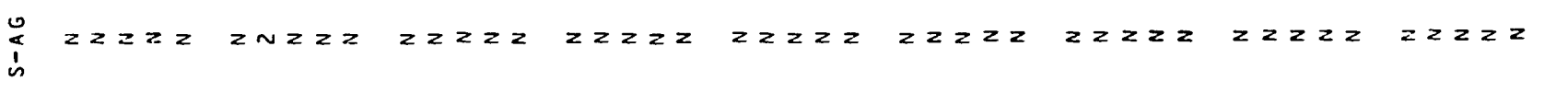

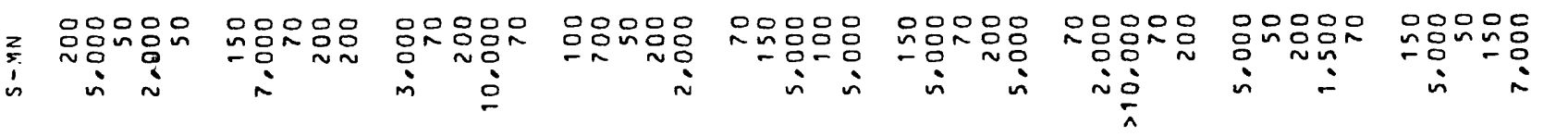

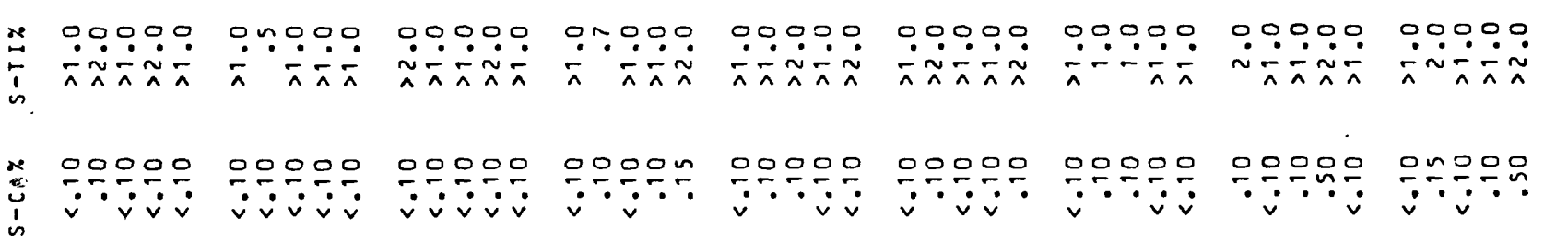

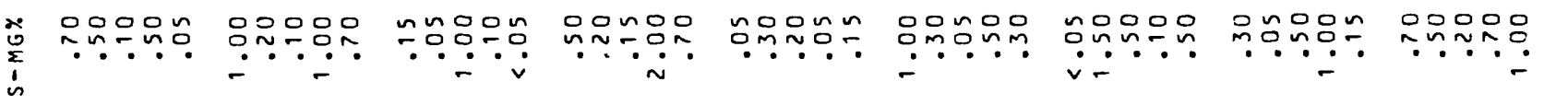

$$
\begin{aligned}
& \text { 昰 }
\end{aligned}
$$

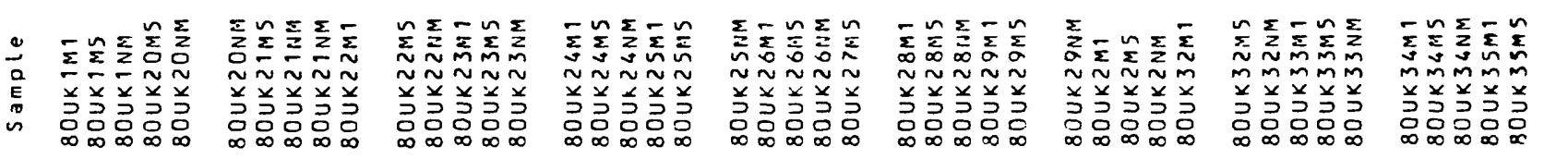




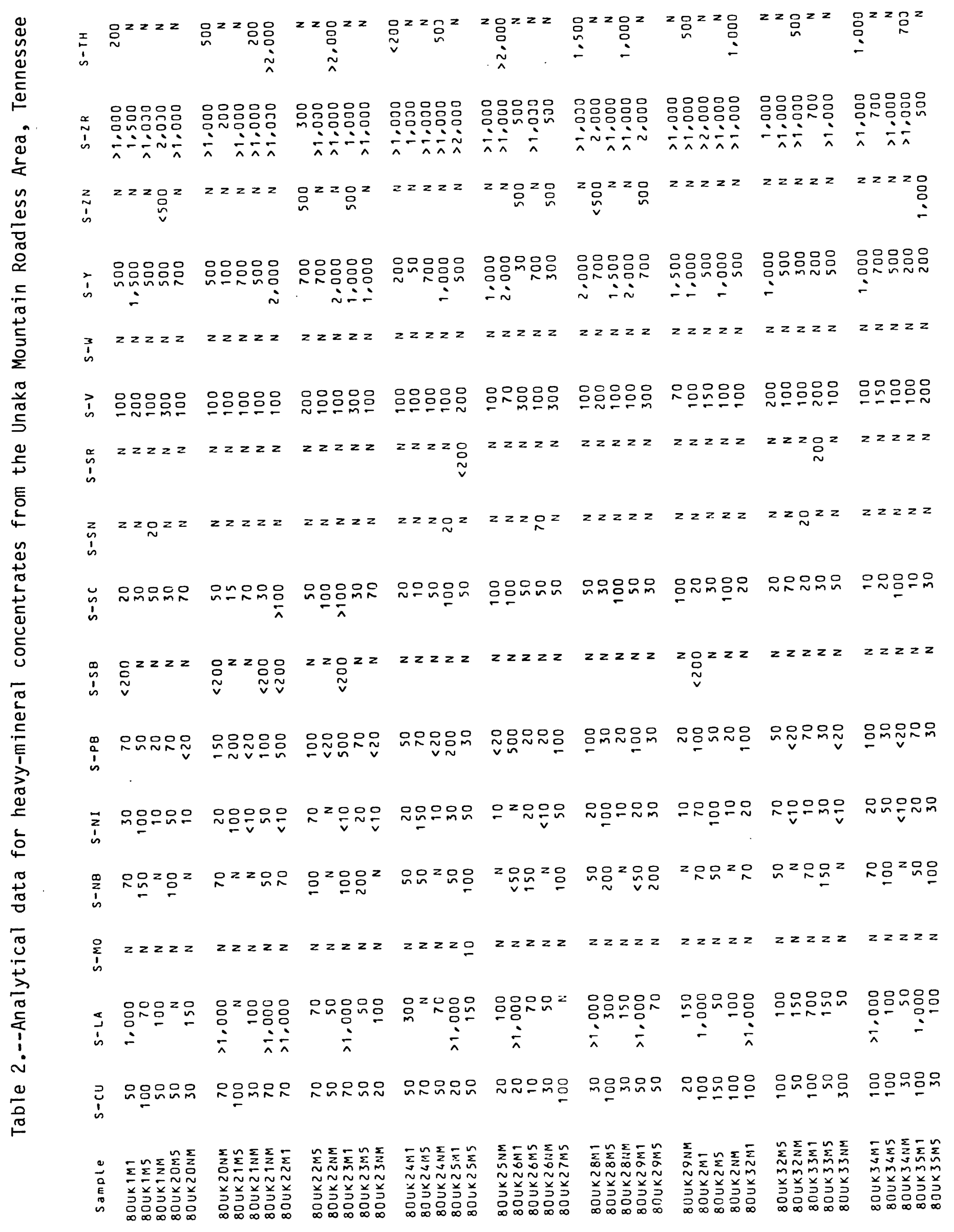


응응ㅇㅇ음

음음응응

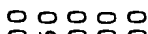

웅웅으음

옹음용 -

m-mn

-

응응으 음음음음

nnn

! !

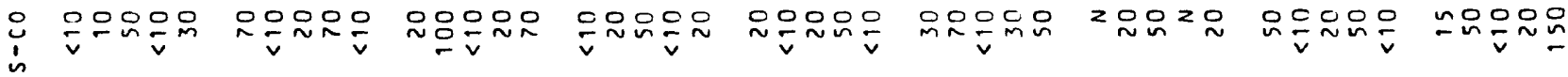

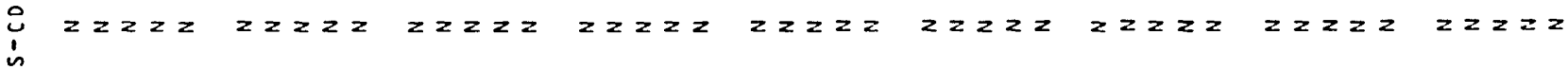

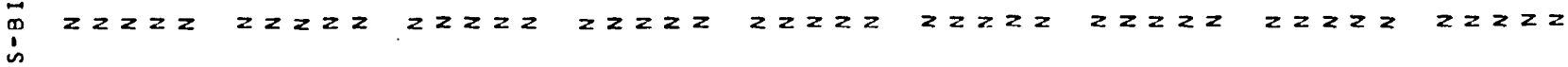

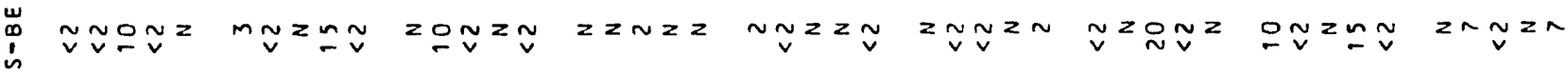

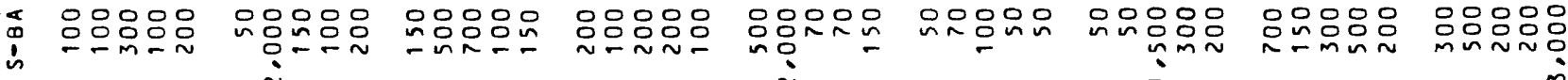

$\frac{1}{4}$

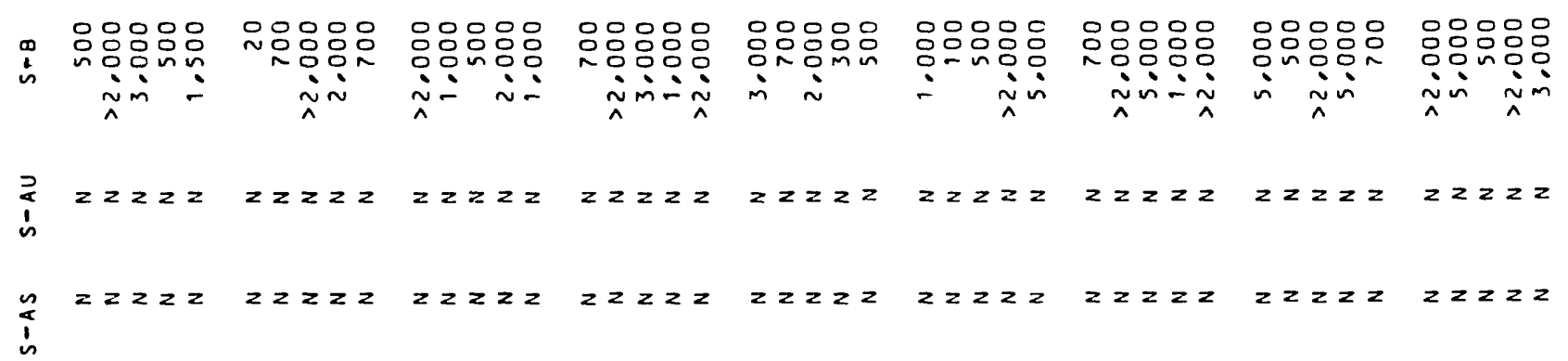

i)

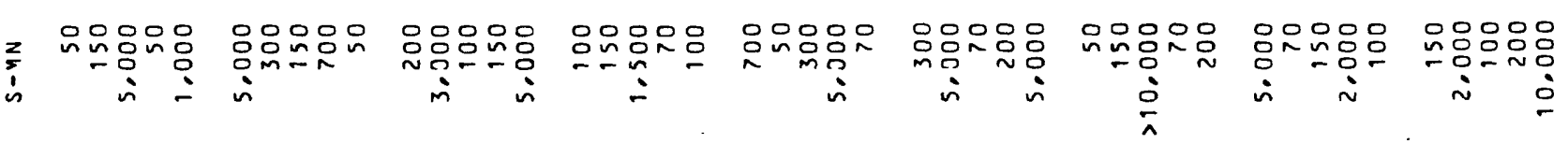

节

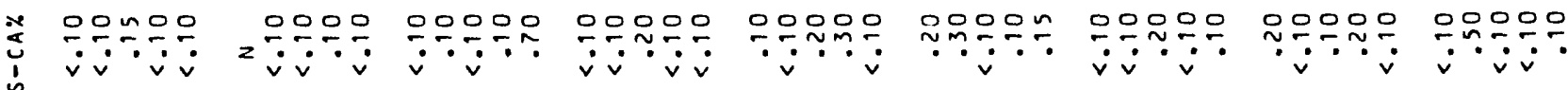

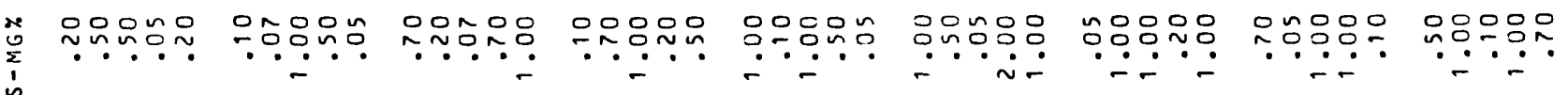

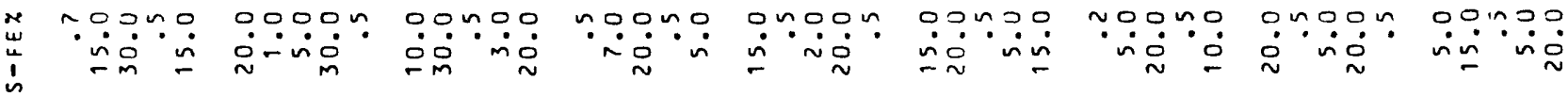

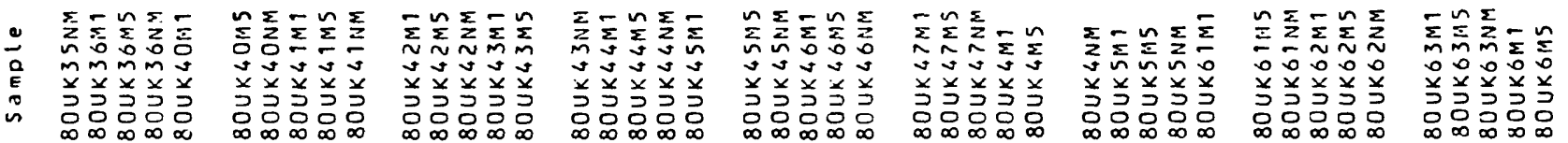




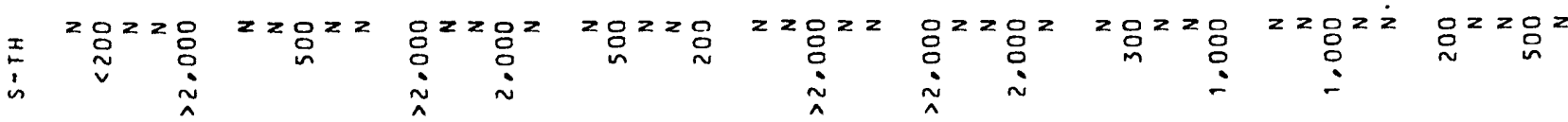

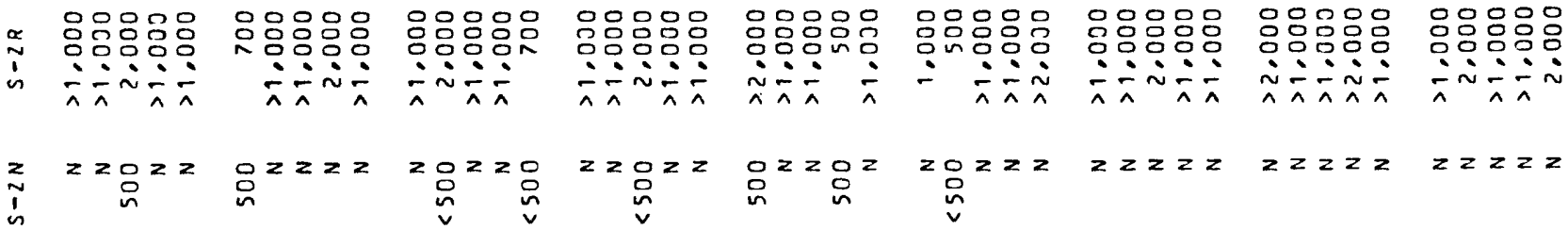

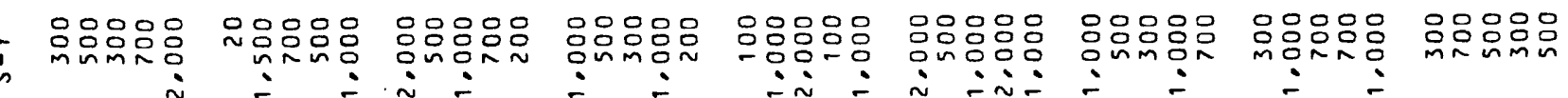
$z z z z z \quad z z z z \quad z z z z z$ $z z z z$ $z z z z=$

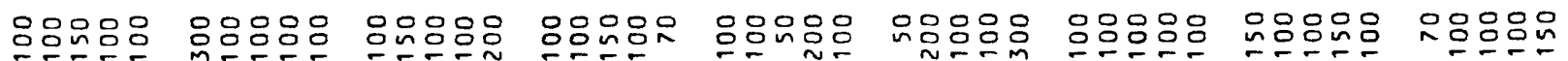

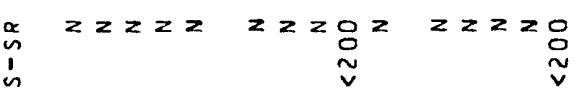
$z 2 z z z=2 z z=$ $z z z z=$ $z=g z z$

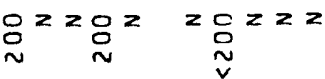

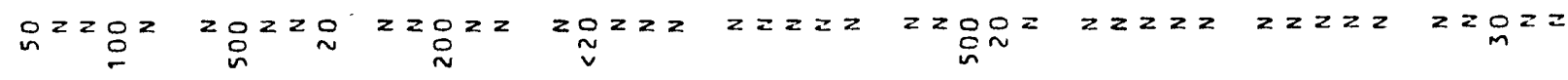

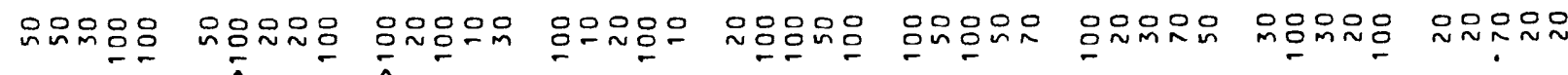

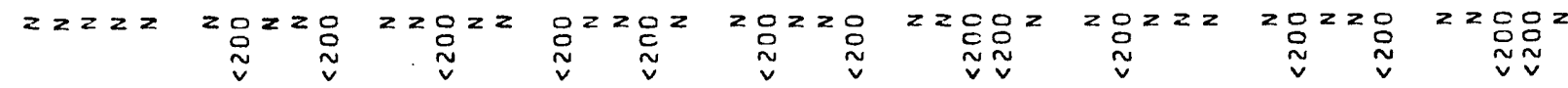

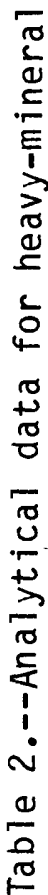

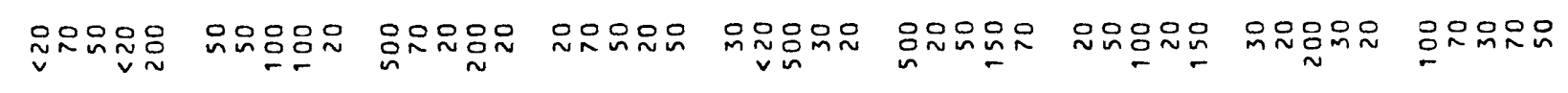

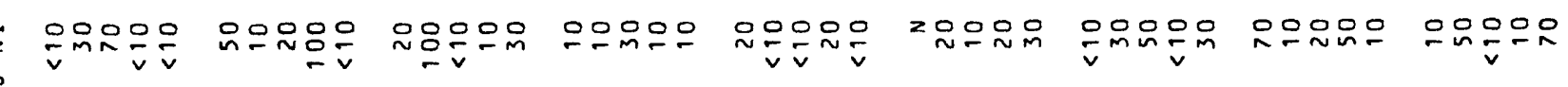

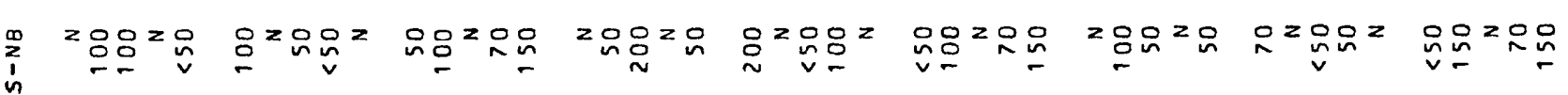

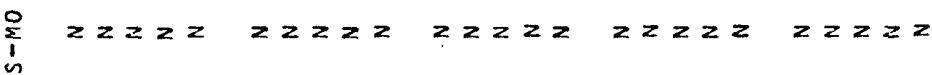

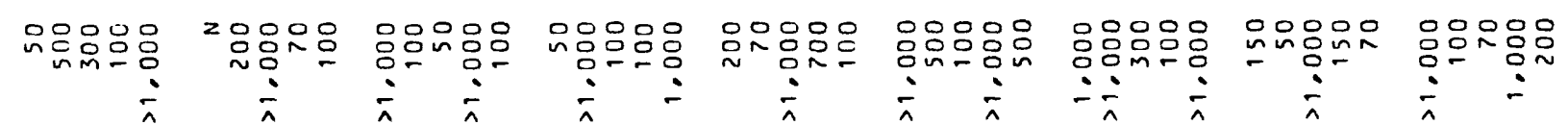

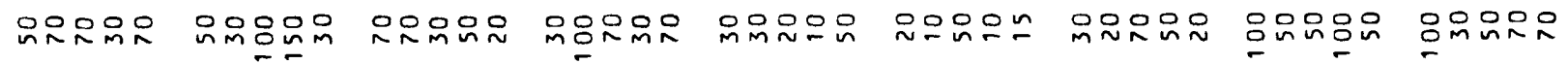
$\sum_{i=1} \sum_{i=1}^{n} \sum_{0} \sum_{0}$ mim

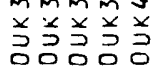

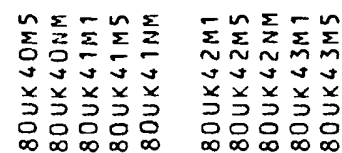

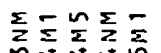

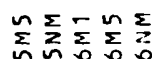

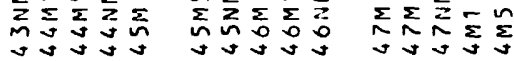

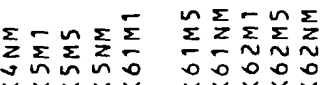

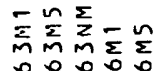

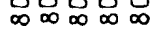




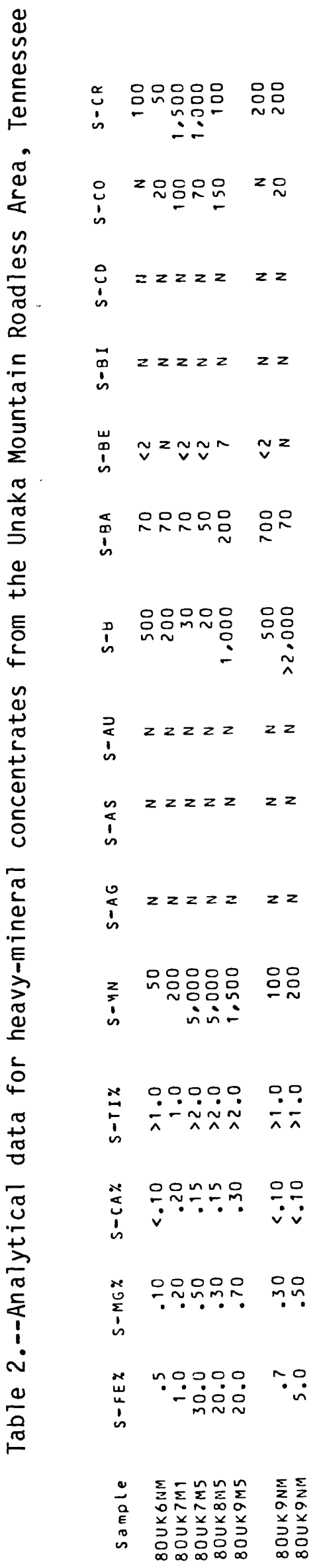




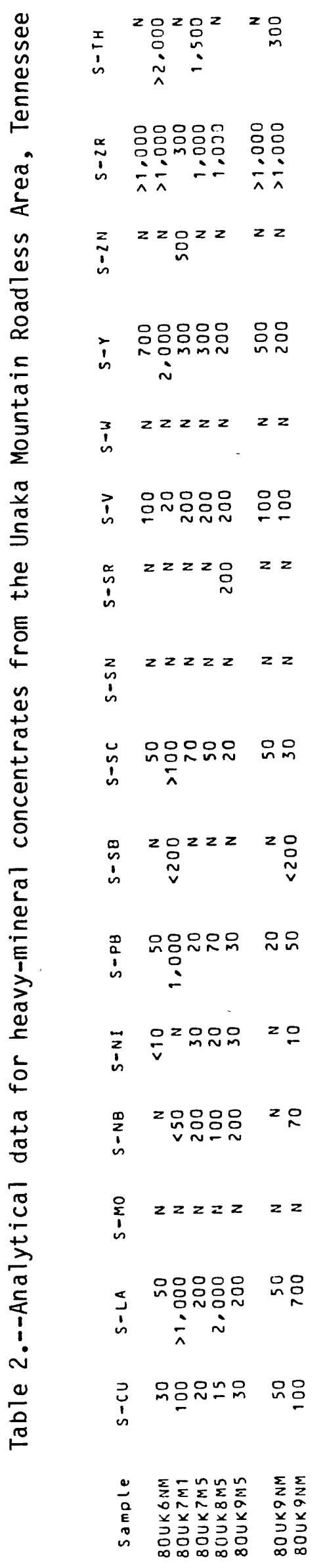

